Ty

Working Papers

\title{
273
}

\section{Age segregation and hiring of older employees: low mobility revisited}

Pekka IImakunnas

Seija IImakunnas 
PALKANSAAJIEN TUTKIMUSLAITOS • TYÖPAPEREITA

LABOUR INSTITUTE FOR ECONOMIC RESEARCH • DISCUSSION PAPERS

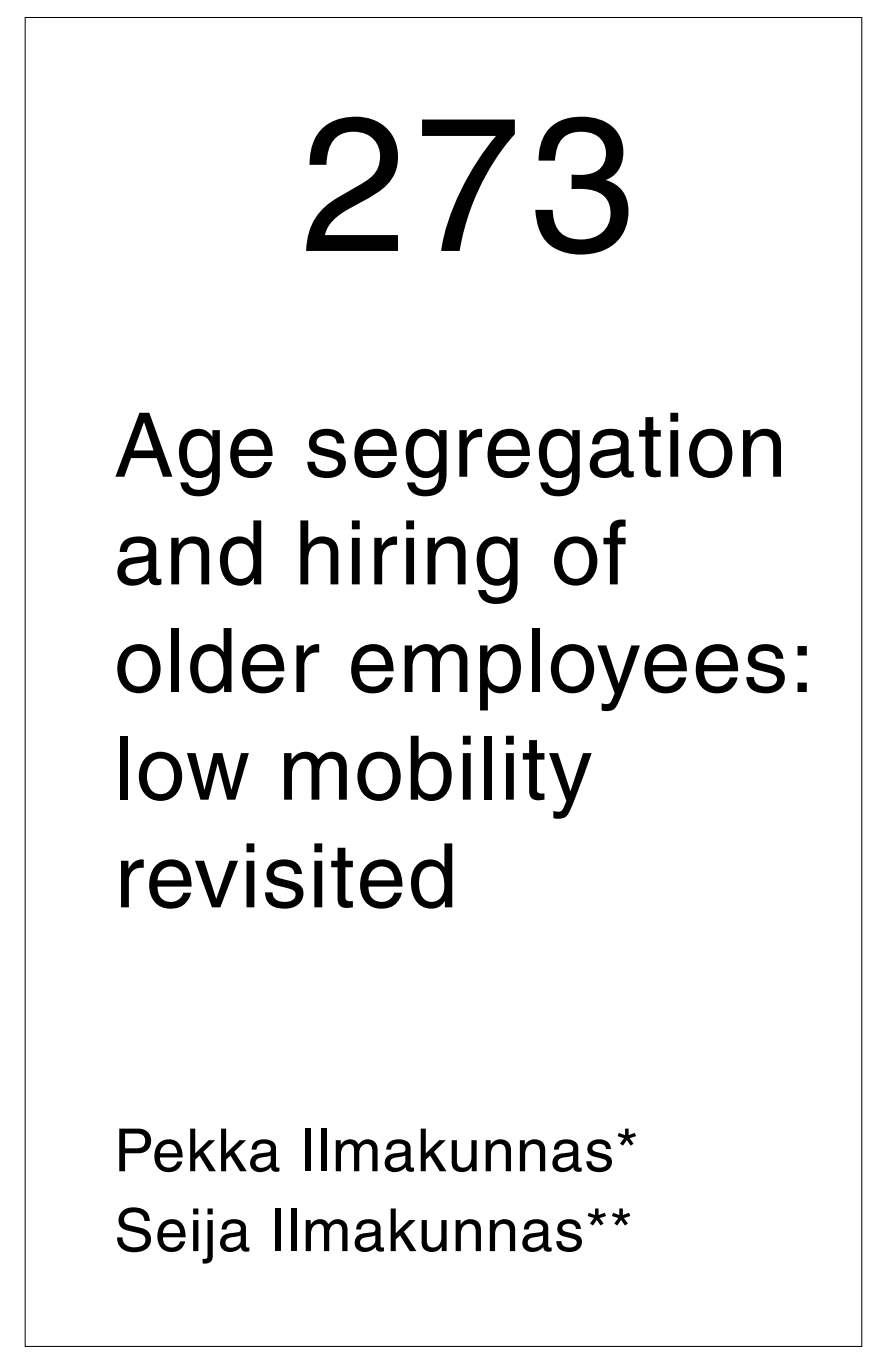

* Aalto University School of Economics and HECER (pekka.ilmakunnas@ aalto.fi)

**Labour Institute for Economic Research (seija.ilmakunnas@labour.fi) 
TYÖPAPEREITA 273

DISCUSSION PAPERS 273

Julkaisija:

Palkansaajien tutkimuslaitos

Pitkänsillanranta 3 A, 00530 Helsinki

www.labour.fi

Helsinki 2012

ISBN 978-952-209-099-7

ISSN 1795-1801 


\title{
TIIVISTELMÄ
}

Tässä tutkimuksessa tarkastelemme linkitetyn työntekijä-työnantaja -aineiston avulla henkilöstön rekrytointeja sekä työsuhteen päättymisiä Suomessa aikavälillä 1990-2004. Aineisto mahdollistaa yritystason tarkastelun edellisvuoden aikana rekrytoitujen ja yrityksestä lähteneiden työntekijöiden kehityksestä. Iän mukaista eriytymistä tarkastellaan sekä segregaatiokäyrien että Gini-kertoimien avulla. Ikääntyneiden työntekijöiden rekrytoinnit ovat yritysten kesken selvästi epätasaisemmin jakautuneita kuin vastaavan ikäisten työsuhteiden päättymiset ja työllisten määrä. Ikäsegregaatio uuden työvoiman palkkaamisessa on kuitenkin hieman lieventynyt tarkastelukauden loppua kohti samalla kun se on lisääntynyt työsuhteiden päättymisten ja työllisten määrän kohdalla. Tulokset saavat vahvistusta lisätarkasteluista, joissa segregaation mittausmenetelmän mahdolliset ongelmat erityisesti pienten yritysten kohdalla tulevat huomioiduiksi. Tarkasteltaessa rekrytointeja ja työsuhteiden päättymisiä aggregaattiaineistolla havaitaan, että vanhimman ikäryhmän rekrytointiosuudet alittavat ko. ryhmän työntekijäosuudet. Heidän rekrytointiosuutensa kasvussa heijastuu ikääntyneiden työntekijöiden lukumäärän kasvu tarkasteluajanjakson loppua kohti, mutta tämä osuuden kasvu jää kuitenkin vaatimattomammaksi kuin ikäryhmän työllisyysosuuden nousu. Suhdannevaihtelut heijastuvat ikääntyneiden kohdalla työsuhteiden päättymisessä mutta eivät rekrytoinneissa. Jaamme lisäksi eri ajankohtina ikäluokkien työllisasteen muutoksen osiin siten, että erotamme siinä toisistaan rekrytointien, työsuhteiden päättymisen ja toisaalta ikäkohorttien koko- ja työllisyysaste-erojen vaikutukset. Lopuksi mallitamme ikääntyneiden rekrytointeja regressioanalyysin avulla. Tulosten mukaan rekrytointiaste jää suurimmissa yrityksissä jälkeen pienemmistä yrityksistä, joskin yrityksen koon kasvu lisää luonnollisesti todennäköisyyttä sille, että yritys ylipäätään palkkaa vanhemman työntekijän.

\begin{abstract}
We analyse age segregation in hirings and separations using linked employer-employee data from Finland in the period 1990-2004. This allows us to identify at the firm level employees in different age groups that have been hired during the previous year, and employees who have exited the firms. We analyze firm-level age segregation using segregation curves and Gini indices. The main result is that hirings of older employees have clearly been more segregated than exits or the stock of old employees even though hirings have become slightly less segregated towards the end of the period in question. At the same time age segregation in exits and stocks has increased and these trends are
\end{abstract}


not sensitive to small unit bias in measurement. We also examine trends in hiring and exit rates using aggregate data. According to our results the oldest age group is again underrepresented in hirings. There is a positive upward trend in their recruitments related to the increasing cohort size, but it is much weaker than the trend in the relative share of older workers in employment. The exit rate of the older employees indicates cyclical variation while the small number of hirings seems to be insensitive to changing labour demand. We present a decomposition of employment change by age group and with that decomposition we disentangle the role of hirings and exits from factors related to demographics and cohort effects. The latter factors include the effect of the large babyboom generation entering the age group of older employees with higher employment rates than earlier cohorts. Finally, our regression analysis shows that larger firms are more likely to hire older employees, but their hiring rates are lower.

Key words: ageing, hiring, segregation, labour demand

JEL codes: J14, J23, J26

\section{INTRODUCTION}

The existing empirical evidence indicates that older employees are less likely to change jobs compared to their younger counterparts, and they are also less likely to become re-employed once unemployed. This scarcity of hirings among older workers actually seems to be a rather universal phenomenon, and this universality makes it interesting per se. However, the ageing of the work force makes it also increasingly policy-relevant.

When the average age of the labour force is increasing, older workers are becoming a more important source of recruitment. Accordingly, firms have to pay increasing attention to their recruitment policies towards older employees. Also from policy perspective it is important to understand the reasons for the reluctance of the firms to hire older employees. In other words, the choice of policy depends also on the nature of barriers to recruit senior workers.

There are competing explanations for scarce recruitments. In the market based explanation the reluctance may arise because of fixed hiring costs and their short payback period in the case of older employees. Senior employees may also have wage expectations that exceed their productivity due to e.g. deferred compensation pay schemes. A further explanation is statistical discrimination where the productivity of possible recruits is evaluated based on the average (observed or assumed) productivity of older employees. On the other hand, the reasons for scarce recruitments may relate 
to labour market and pension policies that have harmful side effects. As an example one can consider pension plans that raise the costs of older employees above those of younger ones. The nature of optimal policy changes is naturally different depending on the underlying reason for scarce recruitments.

We will examine long-term changes in the hiring of older employees over a period of time from the beginning of 1990s to the mid-2000s in Finland. In particular, we examine how age segregated the workplaces are in terms of hiring, exits, and the stock of employees. We also decompose the rate of change in employment of different age groups to their hiring and separation rates and a cohort size effect and examine their relative importance. Special emphasis is given to the relationship between firm size and hiring of older employees.

We proceed by first reviewing the earlier literature on employment opportunities of older workers in Section 2 and policy changes in Section 3. Section 4 then explains the data we use and Section 5 presents descriptive evidence on firm-level age segregation. Section 6 analyses aggregate trends in the hirings and exits of older workers and we present regression results on the determinants of hiring in Section 7. Section 8 concludes the paper.

\section{EARLIER RESEARCH ON THE JOB OPPORTUNITIES OF OLDER WORKERS}

The descriptive work has typically considered the age segregation of hiring compared e.g. to the age segregation of existing employees (e.g. Hutchens 1988; Hirsch et al. 2000; Disney et al. 2006). The underlying question is whether and to what extent the job opportunities of older workers are restricted compared to prime-age workers. The analysis is typically carried out at the occupational or sectoral level so that the location of the most severe entry barriers can be detected. The results typically support the preconceptions that occupational segregation is substantially greater for older hires than for either young hires or employment among all older workers. This implies, among other things, that after major negative macroeconomic shocks the displaced older workers have more limited options of re-entry available.

The widely asked question in the literature follows from these empirical observations: why the firms hire older workers so seldom even though their existing personnel may consist of older employees to a large extent? The theoretical explanations for the firms' reluctance to hire older 
employees propose two underlying mechanisms. The first puts the emphasis on training and fixed costs, while the second puts stress on the nature of optimal labour contracts, especially the so-called back-loaded compensation structures. The latter explanation is then closely connected to the optimal shapes of the age-wage profiles.

The older employees are likely to have a fair amount of work experience and also firm-specific knowledge. Once they are e.g. displaced from their current job, firm-specific knowledge loses its value. It has been even argued that the "managerial culture" they have inherited from their previous work place can actually be a burden from the point of view of the potential new employer (Heywood and Siebert 2009). Anyhow, potential new jobs require new firm-specific training and the fixed costs related to training need to be covered. Here comes the disadvantage of older employees compared to younger recruits: hiring the older employee makes the returns to specific training lower. These returns can be collected only for a relatively short period, because of the short remaining work career of the older employee. The negative relationship between the intensity of training and hiring opportunities of older employees is also verified in several empirical studies (e.g. Disney et al. 2009; Adams and Heywood 2007; Hu 2003).

A very basic element of the hiring barrier is so-called productivity compensation deficit when workers age (Munnell and Sass 2008). While the wage profiles are typically raising or relatively flat even among the oldest, productivity is likely to increase at a slower rate with age or even fall in the same age groups. This clearly forms a disincentive to hiring of older employees. These phenomena have given motivation to the theories that aim at explaining the form of the wage profile which seems to contradict the changes in productivity by age. The origins of these theories are in delayed compensation schemes as formulated by Lazear (1979). There the motivation for rising wage profiles is the embedded incentive structure aiming at long tenures and good work performance. A rising wage profile gives the recruits an incentive to perform efficiently (even without heavy monitoring efforts) in order not to miss the opportunities for rising wages in the coming periods. It is also in their interests to stay with the firm long enough in order to be able to pick up the fruits of good work performance.

Hutchens (1986) developed these ideas further by stating that the implied "delayed payment" contracts also introduce fixed costs (similar to hiring and training costs) into the employment relationship: the firm needs to pay an extra wage premium because in the case of delayed payment the employee faces the risk that the firm cheats (e.g. in the form of ending the employment 
relationship unilaterally). These kinds of fixed costs also make the firms minimize hiring and favour long tenures and they also make young recruits more desirable than the older ones.

While these recruitment strategies may be rational from the point of view of the firms, they make the hiring prospects for older employees less favourable. For instance, it is not profitable for the firm to offer the new old recruits the same wage the existing older employees within the firm have. On the other hand, offering a wage too different from the existing wage level may harm the work performance of the newcomers. This contradiction is likely to result in the firm choosing young recruits instead of old ones. Since the introduction of these ideas they have been tested in many studies (e.g. Hutchens 1986; Adams and Heywood 2007; Heywood et al. 2010; Daniel and Heywood 2005; Hirsch et al. 2000; Zwick, forthcoming; Pfeifer 2009). The empirical evidence quite consistently confirms the theoretical outcomes according to which firms with deferred compensation hire a smaller share of older workers.

The literature on back-loaded compensation also deals with the different kind of hiring behaviour of large and small firms. Long employment contracts are likely to be more important for large firms. This relates e.g. to the preconception that large firms typically invest more in firm-specific human capital introducing higher fixed training costs. Furthermore, the larger internal labour markets make it easier and also profitable to have long tenures. One may also assume that in larger firms the monitoring costs rise above the similar costs in smaller firms making the steeper wage-tenure profiles more likely. All in all, on theoretical grounds larger firms would be less likely to hire old employees than small firms. While some empirical evidence gives support to this reasoning (e.g. Hu 2003; Adams and Heywood 2007), there is also evidence pointing to the opposite direction (Heywood et al., 2010).

There are also some studies that put more emphasis on institutional arrangements that may hamper the hiring opportunities of older employees. The relevant institutional arrangements include health and pension insurance systems and also employment protection and anti discrimination legislation (see e.g. Scott et al. 1995; Garen et al. 1996; Daniel and Siebert 2005; Adams 2004; Behaghel et al. 2008). While these policies may have well-founded welfare motivations, they may introduce as byproducts negative implications for the hiring prospects of older employees. Particularly, they may increase the costs of new potential recruits adding to the problem of wage-productivity gap among the older employees. 
The results of the relevant empirical studies generally confirm the view that the policies in question can indeed have harmful effects on hiring prospects. ${ }^{1}$ On the other hand, the magnitude of these effects is naturally dependent on the actual implementation of the schemes. In the case of the pension schemes, for instance, the relevant question is to what extent also the employer-provided pension plan is back-loaded.

\section{THE INSTITUTIONAL SETTING: REMOVING BARRIERS TO LONGER WORKING CAREERS}

Finland has witnessed a clear change in pension policy during the last 15 years. The aim has been to lengthen working careers and the most distinct elements of this change are the restrictions in early retirement options. Simultaneously employment of ageing workers has increased at record speed among EU15 countries since the late 1990s until mid 2000s (Ilmakunnas and Takala 2005). The improvements in employment rates were manifested both in the age groups 55-59 and 60-64.

In the early 1990s Finland still was a typical example of early exit culture and the exit routes were many-fold. They were related to: (i) disability (three different schemes), (ii) unemployment (socalled unemployment tunnel with extended UI benefits plus unemployment pension), and (iii) reduction of working hours (part-time pension). Step by step the policy has been shifted away from the early exit culture (Ilmakunnas and Takala 2005). The lower age limits of early retirement schemes have been raised and the early exit routes have become economically less tempting to both employees and their employers. In short, these reforms have made the easy ways to discontinue the current employment contract less seldom available and economically less beneficial to both sides.

The effects of these restrictions on exit rates from work to unemployment and early retirement and on exit routes from unemployment have been studied at the individual level (Hakola and Uusitalo 2005; Kyyrä and Wilke 2007; Kyyrä and Ollikainen, 2008). The above studies have indicated that these reforms have postponed withdrawals from the labour market and the outflow rates from employment to unemployment and to early-retirement schemes have diminished remarkably during this period.

\footnotetext{
${ }^{1}$ See Ilmakunnas and Ilmakunnas (2011) for references on the research dealing with hiring of older employees where policy changes have been used for obtaining exogenous variation in the costs (or incentives) of hiring older employees.
} 
These results are in line with the original motivation of the policy reforms which have aimed at the continuation of existing employment contracts. While the effects on recruitments have not been the primary motivation, the hiring decisions can also be affected by the reforms. The effects on hirings stem from the fact that the removals of early retirement options are likely to lengthen the expected working careers of the potential older recruits. This implies, among other things, that the hiring costs are then less harmful for the firm because these costs can be recouped during a longer period (Saint-Paul 2009). Also Hairault et al. (2010) have argued that the time to retirement determines to a large extent the value of an employment contract.

For the above reasons we set the hypothesis that the restrictive changes in early exit policies are also reflected in improved hiring prospects for older employees. However, empirical analysis is needed because there might be other forces working in other direction. For instance, firms have used the early exit options as an easy way to lay off employees in periods of declining demand. The restrictions have hit especially those exit routes where the firms have acted as a "gatekeeper", i.e. where the decisions on the use of the routes have mostly been made by the firm. This abolition of the possibilities for easy work force reductions may actually make firms more reserved to hire older workers. We are interested in the trends in the hiring of older workers over a long time period during which several reforms have happened. Therefore we cannot use the reforms as "natural experiments". Such analysis would require attention to a narrowly defined time period (see Ilmakunnas and Ilmakunnas, 2011).

In addition to changes in hiring trends we are also interested to the recruitment patterns in firms of different size. The motivation for this raises from experience rating, whereby firms above certain size thresholds directly cover a predetermined share of pension outlays between early retirement and start of old age pension of their employees (see Ilmakunnas and Ilmakunnas, 2011). The motivation for this kind of financing structure is to discourage especially the larger firms from inefficiently overusing early retirement as a tool of labour adjustment. While experience rating may indeed reduce exits to early retirement channels, it may at the same time make bigger firms more cautious in hiring of older workers. 


\section{THE DATA AND KEY VARIABLES}

We use data drawn from the Finnish Linked Employer-Employee Data (FLEED) 1990 - 2004, which include information on plants and firms and the employees who can be linked to their employer. The FLEED data set merges comprehensive administrative records of all labour force participants in Finland as well as all employers (firms and their plants) subject to value added tax. The data on individuals cover the whole working age population and have information (code) of the employer plant and firm of the individuals at the end of the year. The codes allow linking of data on individuals to employers with near-perfect tractability over time.

We use a sample of FLEED, with such information on firms and plants that guarantees that the employers cannot be identified. The sample data cover the years from 1990 to 2004. Every third individual in age group 16-69 years is randomly included in the sample in the year 1990. This sample includes ca. 1 million individuals. For these individuals, all information from the subsequent years 1991-2004 is included. Starting from 1991, in each year a third of all 16 years old persons are selected to the sample and these individuals are included in the sample in all subsequent years. For each individual in each year, the data on the plant and firm that she is working in is included. As a result, the plant and firm panels cover practically the whole populations of plants and firms for all the years, but the person panel is a sample.

There have been many ways to form the variable to be explained in econometric work in earlier research in which the age structure of hiring has been analyzed. If the analysis is carried out at the firm or plant level one can either relate the number of old hires (the definition of old varies) (i) to the total number of people hired, (ii) to older existing employees within the firm, or (iii) to the total number of the personnel. Newly hired workers are typically defined as those hired during the previous year or during the previous few (often last 1-5) years. In addition to the firm-level analyses another approach has been to use individual-level data on new hires and explain the probability that a new hire is old (e.g. Scott et al. 1995; Adams and Heywood 2007). We use firm-level data and measures that are close to (i) and (ii) above. Further, we concentrate on hiring during the previous year and we will subsequently call the age group 50-64 "old” employees.

The main variables of interest are the flows of employees to and from firms. We analyse them both at the level of the whole private non-farm business sector and at the firm level. The flows are disaggregated by age. We use the age division 20-29, 30-39, 40-49, and 50-64 years. We thus leave out the youngest (below 20) and oldest (above 64). To obtain more observations per firm (as in 
many cases the number of hired employees is small, especially when we disaggregate hiring by age) we keep only the firms with at least ten employees in the total data although they may have less than ten observations in our sample data.

We use two measures for age-related hiring rates. The first is the share of an age group in hiring, $h_{j t} / h_{t}$, where $h_{j t}$ is the number of hired employees (from unemployment, out of labour force, or other jobs) between $t-1$ and $t$ of age $j$ in $t$ and $h_{t}$ is total hiring. The age is based on age in year $t$, so the hiring of 50-64 year olds, for example, counts those who were 49-63 years old in year $t-1$. Similarly we define the shares of an age group in exit (to unemployment, out of labour force, or other jobs) and the stock of employees as $e_{j t} / e_{t}$ and $n_{j t} / n_{t}$, respectively. The second measure is the hiring (and exit) rate of an age group. The hiring rate for age group $j$ in year $t$ is $h_{j t} / \bar{n}_{j}$, where the denominator $\bar{n}_{j}=\left(n_{j, t-1}+n_{j t}\right) / 2$ is the two-year average number of employees in the age group. Correspondingly, the exit rate is $e_{j t} / \bar{n}_{j}$, where $e_{j t}$ is the exit in age group $j$.

Using the average employment in the denominator in the rates, we can treat the hiring and exit rates symmetrically. However, the difference of the age group hiring and exit rates does not give the rate of change in the age group, since the number of employees in a group also changes through the ageing of the staying employees. For example, those who were 64 years old last year no longer belong to the group 50-64 this year, whereas those who were 49 years old last year, now belong to that group. The change in employment in the 50-64 age group can be expressed as $\Delta n_{50-64, t}=h_{50-64, t}-e_{50-64, t}+\left(n_{49, t-1}-n_{64, t-1}\right)$. Dividing this expression by the average employment $\bar{n}_{50-64}$ gives us the rate of change in the age group. It is decomposed to the difference of the hiring and exit rates plus the "cohort effect", which is the difference of the 49-year olds and 64-year olds last year in relation to average employment in group 50-64: ${ }^{2}$

$$
\Delta n_{50-64, t} / \bar{n}_{50-64}=h_{50-64, t} / \bar{n}_{50-64}-e_{50-64, t} / \bar{n}_{50-64}+\left(n_{49, t-1}-n_{64, t-1}\right) / \bar{n}_{50-64}
$$

Similar expressions can be written for the other age groups. Note that the difference of hiring and exit is the change in employment for a cohort that was 49-63 years old in $t-1$ and 50-64 years old in $t$, whereas the whole equation (1) compares 50-64 year olds in $t$ to 50-64 year olds in $t-1$.

\footnotetext{
${ }^{2}$ Note that the cohort effect is related not only to cohort sizes, but also to labor market attachment of different cohorts at different ages.
} 


\section{AGE SEGREGATION AT THE FIRM LEVEL}

To gain insights on the firms' hiring behaviour of older employees, we illustrate in Figure 1 the distribution of hiring across firms with segregation curves. Firms with at least ten employees are first ordered according to the ratio of old (50-64) employees and young (20-49) employees, separately for stocks, exits, and hires. Then the cumulative share of younger employees is plotted against the cumulative share of older employees. If the distribution of older and younger employees is the same in all firms, the curves would lie along the 45 degree line. The further the curves are from the line, the more segregation there is. The curves are shown for the years 1994 and 2004 . The area between the 45 degree line and a segregation curve is the Gini index $G$ for segregation. Normalizing the area of the triangle to unity, the index is between zero and one. In practice, we calculate the Gini index as $\mathrm{G}=\sum_{i} X_{i-1} Y_{i}-\sum_{i} X_{i} Y_{i-1}$, where $X$ and $Y$ are the cumulative shares of the young and old, respectively, and $i$ is the rank of the firm in the ordering (Duncan and Duncan, 1955). The left panel of Figure 2 shows the development of the Gini indices of the stock, exits, and hiring of older employees over time.

\section{Figure 1. Age segregation curves.}

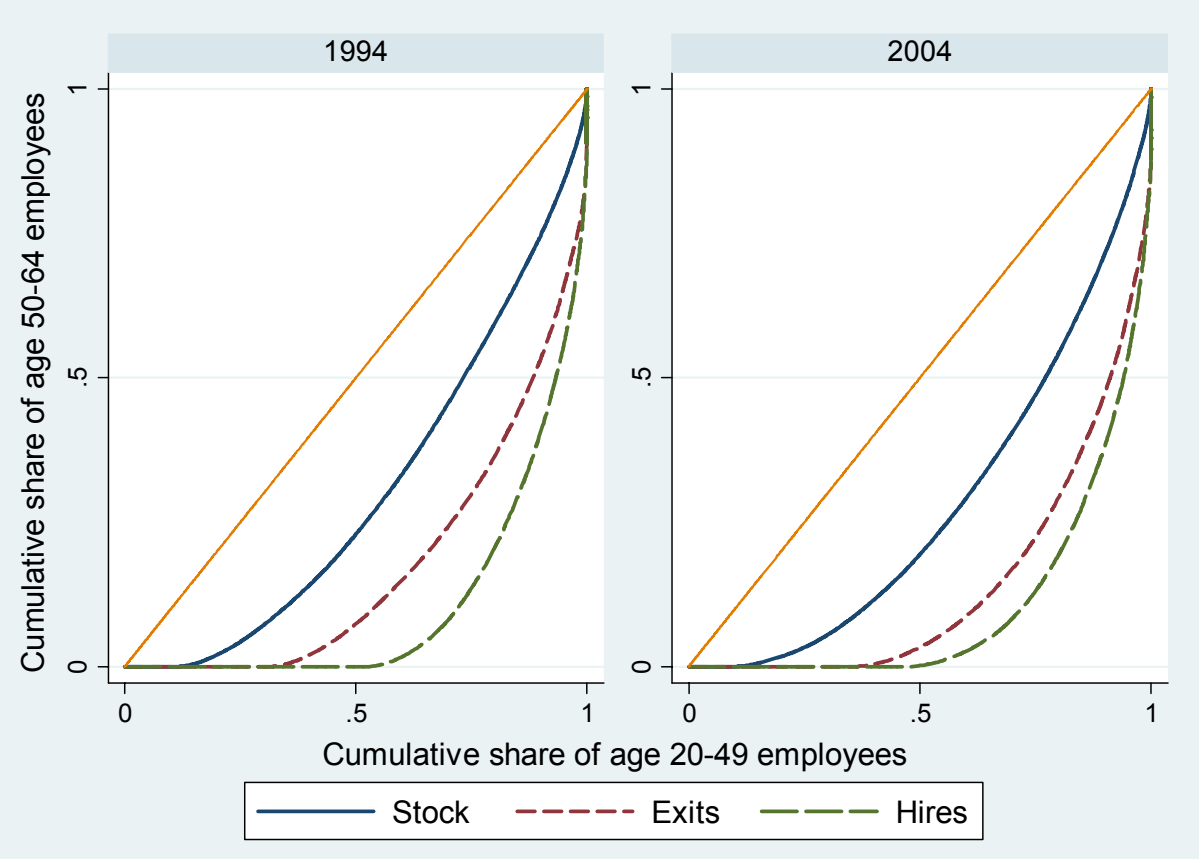


Figure 2. Time series of Gini indices.

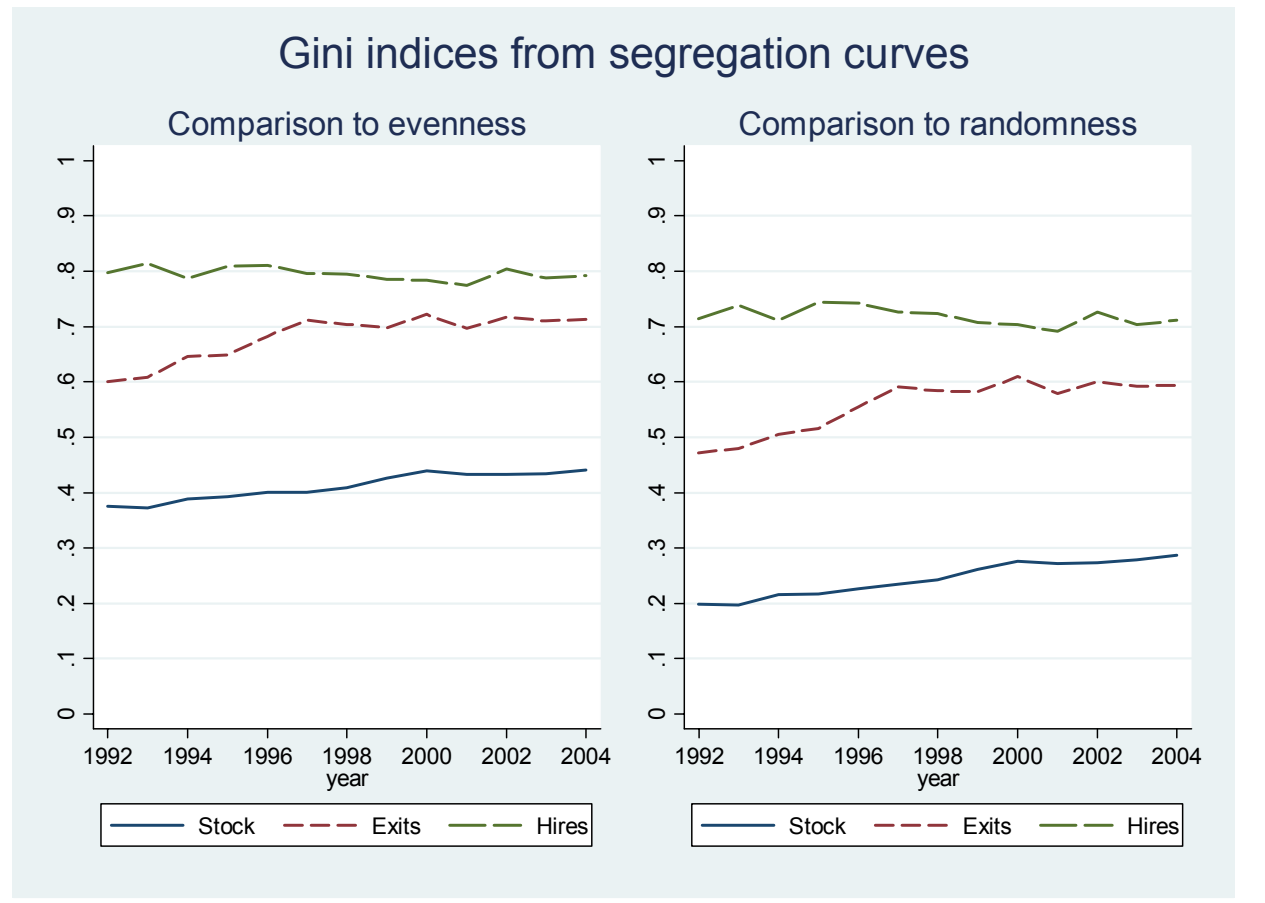

Two conclusions can be drawn from the graphs. First, hirings of older employees are much more segregated than exits and they both are in turn more segregated than the stock of older employees. Roughly 50 percent of hirings of below 50 year old employees have happened in firms that did not hire older employees (in the sample data). Second, over time the stock and especially exits of older employees have become more segregated, but there has not been much change in hiring segregation. As a result, the curves in Figure 1 are closer to each other in 2004 than in 1994, and the curves in the left panel of Figure 2 showing the Gini indices for exits and stocks have positive trends. In the 2000s segregation has no longer increased.

It has been argued that the Gini index may give a misleading picture of segregation when the units are small (Carrington and Troske, 1997). In our case the index is calculated comparing segregation to the case, where the share of old is the same in all firms (i.e., the 45 degree lines in Figure 1). However, we have a relatively small number of observations of old hires and exits for the smaller firms, and it may not be possible to have exactly the same share of old and young as in the aggregate data. An alternative comparison is the case of random allocation of the employees to firms, which can generate uneven distribution without being segregation. Carrington and Troske (1997) suggest a modification to the Gini index. It is the area between the original segregation curve and a corresponding curve of randomness (obtained from random reshuffle of employees to firms) 
as a proportion of the whole area under the curve of randomness. In practice, this is obtained by calculating a Gini index $G^{*}$ for the curve of randomness and modifying the original Gini index $G$ as $\left(G-G^{*}\right) /\left(1-G^{*}\right)$. We have calculated the Gini indices also in this way, doing the reshuffle separately for the stocks, hires, and exits 100 times each year. The value of $G^{*}$ used in the adjustment was the mean of the Gini indices from the reshuffles for each year. Figure 3 shows segregation curves that correspond to one specific reshuffle for each variable in 1994 and 2004. The right hand panel of Figure 2 shows the adjusted Gini indices.

\section{Figure 3. Age segregation curves, random allocation of workers.}

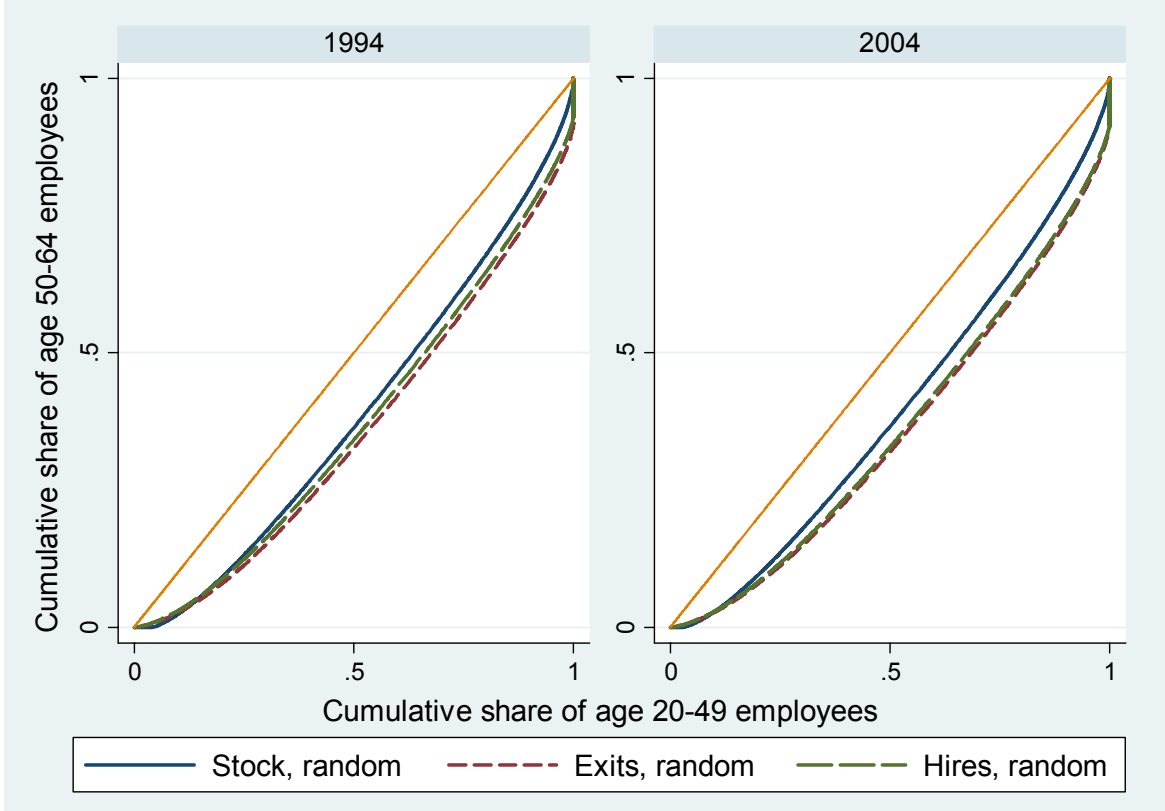

In Figure 3 the random allocation graphs are below the 45 degree line, showing that part of the observed segregation may indeed be a result of random factors. Even with random reallocation of workers, hires and exits are more age segregated than the stocks of workers. Interestingly, there is not much difference between hires and exits in Figure 3, whereas the difference in their segregation was clearly visible in Figure 1. The values of the adjusted Gini indices in the right hand panel of Figure 2 are lower than the unadjusted ones in the left hand panel, and the differences are significant. If the adjusted index $G^{*}$ is calculated separately for each reshuffle, the 99 percent interval around the mean of the index is such that the index $G$ calculated from the actual data is outside the interval. This holds for all of the variables (hirings, exits, stocks) in all of the years. The trends and changes in the curves are very similar. Our conclusions on the development of segregation over time are therefore not sensitive to small units. The relative degrees of segregation 
of stocks, hires, and exits, are, however, slightly different, as the adjustment has less impact on the Gini indices of hiring than on the indices for exits and stocks. The adjusted indices reinforce the impression that hirings are much more age segregated than exits or the stocks of workers.

\section{TRENDS IN AGGREGATE DATA}

In the analysis of the aggregate flows our first interest is in the shares of the age groups in total hirings and exits. Then we turn to analysing the corresponding rates where the flows are calculated in relation to the number of the employed in that particular age group. Finally, we decompose changes in employment in different age groups. There our aim is to consider especially the relative roles of hirings, exits and varying cohort sizes behind the increasing employment rates among older work force.

Figures 4 and 5 show the development of the shares of different age groups of the stocks, hirings, and exits of employees. The figures show the same information expressed in a slightly different way. In Figure 4 we compare the age groups for different flows separately, whereas in Figure 5 we compare the flows for each age group separately.

Figure 4 reveals that young employees tend to be the most mobile. The youngest age group accounts for a high share of hires and that share has increased over time. The young also have a fairly high share of exits. Especially the hiring shares show clearly the decreasing mobility by age. The stock shares of the age groups are closer to each other and the shares have converged over time. Part of the variation in the shares is the results of demographics as the baby boom cohorts born in the late 1940s and beginning of 1950s are larger than the younger cohorts. 
Figure 4. Age group shares by type of flow.

Shares by age group
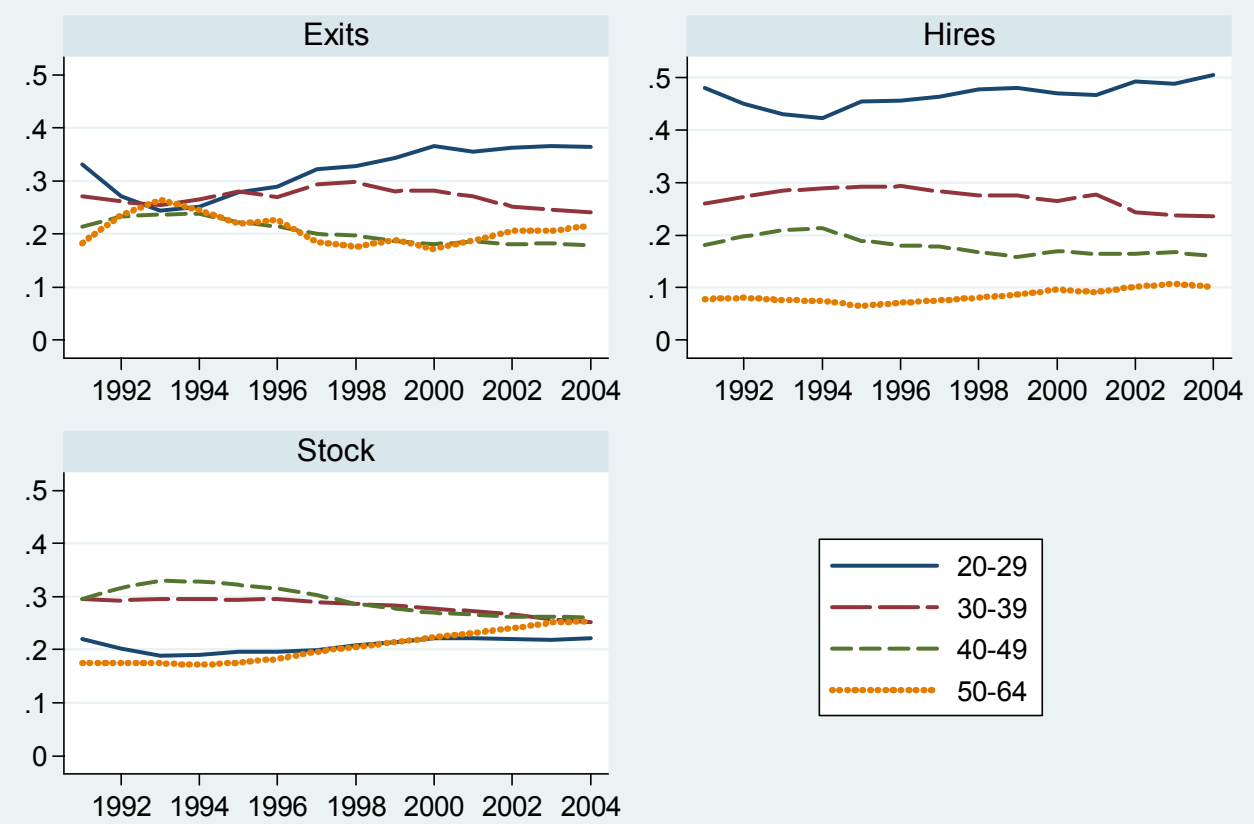

1992199419961998200020022004

Figure 5. Shares of flows by age group.

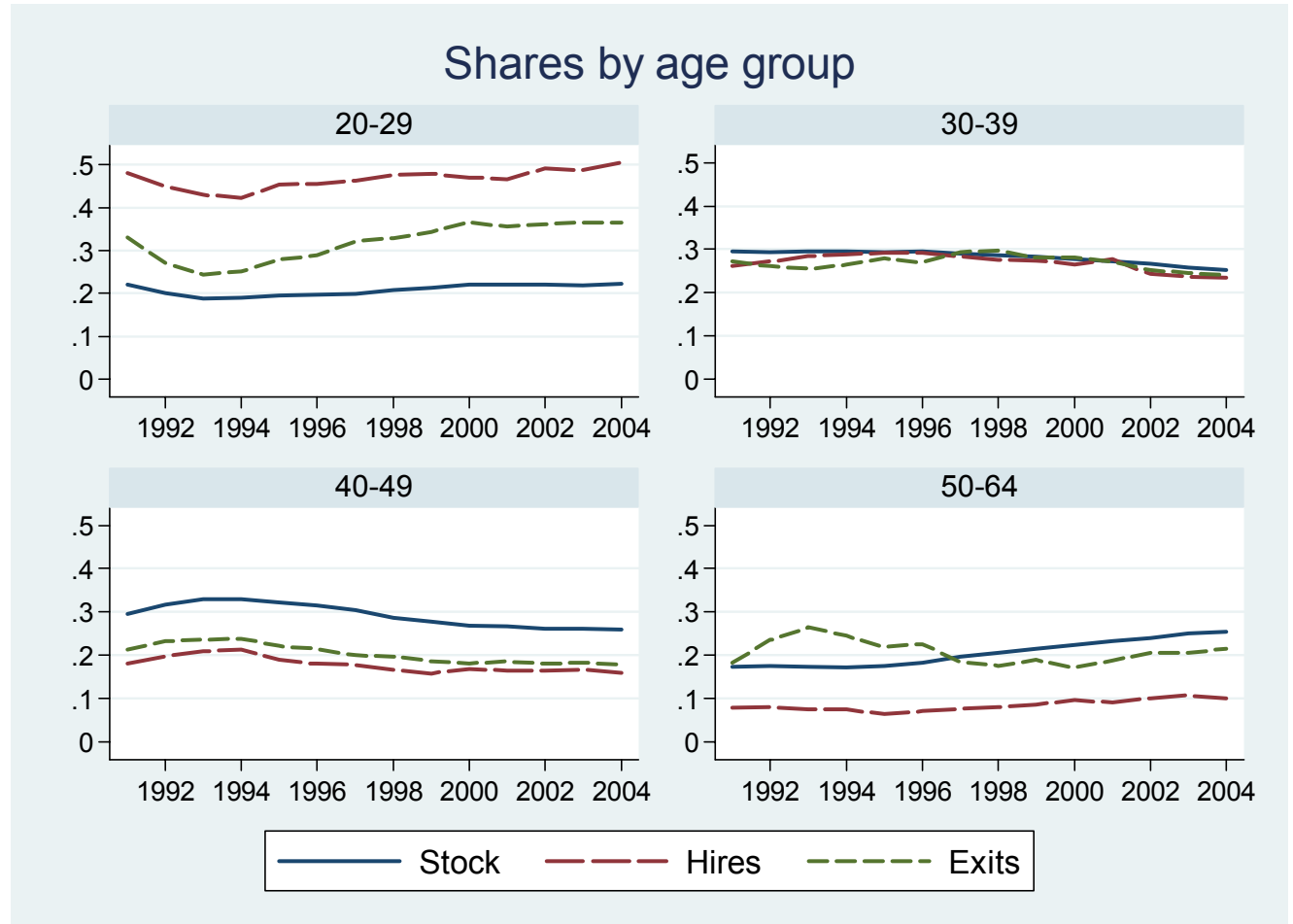


From Figure 5 we can see that the youngest age group 20-29 is overrepresented both in hiring and exits, compared to its share in the number of employees. Interestingly, in the age group 30-39 the hiring, exit, and stock shares are almost equal. The 40-49 year olds have a lower share of mobility than what their stock share is. The oldest age group 50-64 is underrepresented especially in hiring. Although there is an upward trend in the hiring share, it is much weaker than the trend in the stock share. This shows that although the hiring of older employees to some extent follows the cohort size, there are other factors that slow down hiring. These may include lower incentives to hire older employees, but also their lower tendency to switch jobs. The exit share of older employees has fluctuated much more than the other shares. Especially in the recession experienced in Finland in the early 1990s older employees have accounted for a disproportionate share of exits. Although we have not separated here the exits by destination, exits to unemployment and retirement are the dominant destinations in this age group. The Finnish unemployment pension system has made it attractive for firms to concentrate labour shedding to the older workers. Naturally, the exit share of the old is close to their stock share, as this age group represents the end of the working career for most employees.

Figure 6 shows the hiring and exit rates and the decomposition of the rate of employment change to the "cohort effect" and the difference of hiring and exit rates. The hiring rate among the youngest shows much variation over time, but with older age variations in the hiring rate become much smaller and in the oldest group, 50-64 olds, the exit rate varies clearly more. The recession in the early 1990s meant very high exit rates for the older employees, but their hiring rate is very low and it shows hardly any cyclical variation. The net effect of hirings and exits declines with age, becoming negative among the oldest. However, it has been relatively stable in all of the age groups in the 2000s. The "cohort effect" has contributed negatively to employment change in the youngest age group 20-29 and positively in the oldest group 50-64, but it is close to zero in the two other groups. The 49-year olds with relatively high employment rates entering the oldest age group have been larger than the cohorts of the 64-year olds who have left the group. Furthermore, the large baby-boom generations born after World War II increased the inflow to the oldest age group in the mid 1990s. This effect was strengthened by their employment rates that where typically higher than the ones of older cohorts. 
Figure 6. Decomposition of the rate of employment change.

Flow rates by age group

20-29

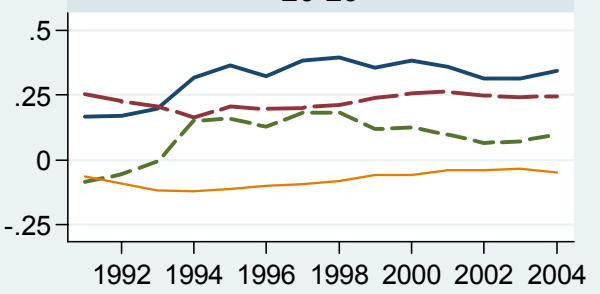

$40-49$
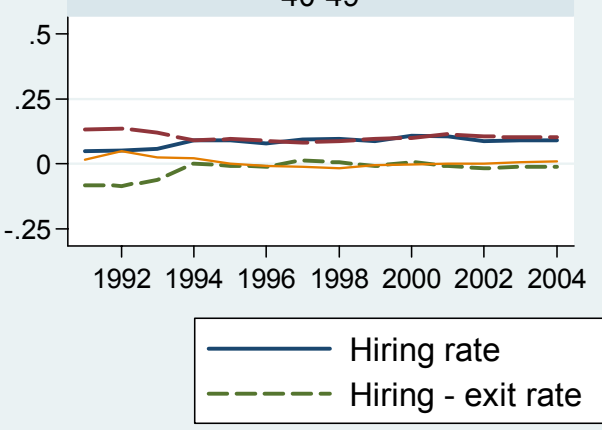

30-39

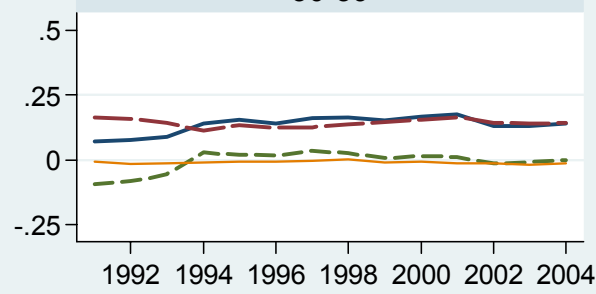

50-64

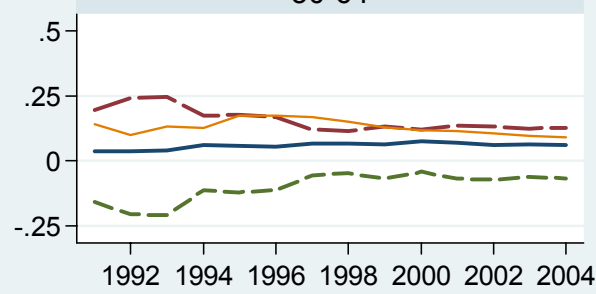

Exit rate Cohort effect

\section{ESTIMATION RESULTS}

We present regressions where we examine whether the determinants of hiring of older employees have changed over time. Our main attention is on the firm size effects. We use both the hiring share of older employees and the hiring rate as dependent variables. In all of the estimations we use weighting by the two-year average employment (in the sample data) to account for the fact that the dependent variables are likely to have higher variances in small firms.

There are many observations, where the rates are zero. These zero observations are corner solutions, as the hiring rates cannot be negative and therefore there is no censoring. In principle we could use Tobit models, but they have the disadvantage that the explanatory variables are assumed to have the same sign in the determination of non-zero observations and in the continuous part of the model. Selection models could account for different effects, but it is hard to justify exclusion restrictions, i.e. to find variables that would affect the choice of hiring older employees, but not the choice of how many of them to hire. Therefore we use a two-part model where the discrete and continuous parts are treated separately. In any case, when weighted estimation is used, the zero observations do not matter as much and often OLS for all observations gives more or less the same results as 
nonlinear models where the selection part and continuous is taken into account at the same time (see e.g. Ilmakunnas and Maliranta, 2005).

The explanatory variables include several indicator variables: dummy variables for size groups of the firms ${ }^{3}$ (number of employees is 10-19 (reference group), 20-49, 50-99, 100-299, 300-), a dummy for foreign ownership (at least 20\% share), dummies for exporting and importing plants, and dummies for 24 two-digit industries ${ }^{4}$. There are also several continuous variables: employment growth rate, exit rate (or exit share) of employees in the same age group that is used as the dependent variable, productivity (log of total factor productivity, lnTFP), average educational years (based on standard degree years), average tenure years, and average age of the employees. ${ }^{5}$ To reduce endogeneity concerns, we lag all the continuous variables by one year. In this way the hiring rates cannot affect the work force structure, and the other variables do not perfectly coincide with the hiring flows which are defined by a comparison to year $t-1$ situation.

The time paths of the firm size coefficients are shown in Figure 7. They are based on separate annual cross section estimates. ${ }^{6}$ The group of larger firms has lower hiring shares of the old than the smallest firms (size groups 10-19 and 20-49). When we include only positive hiring share observations, the hiring rate falls even more clearly with firm size. In all of the size classes the hiring rate of old employees has been higher than in the reference group, firm size 10-19, in most of the years. There is, however, a downward trend in the coefficients and some of them become negative in the 2000s. The differences between firms in different size classes are relatively small. Again, using only the positive observations shows a clear, declining relationship between firm size and hiring rate of the old. For the discrete part we use a linear probability model. The results show that the probability of hiring older employees increases with firm size. The hiring behaviour of firms is therefore a product of the higher propensity of the large firms to hire older employees and their lower rate of hiring when they hire any.

\footnotetext{
${ }^{3}$ Because of data confidentiality, we have no information on the actual sizes of the firms, but we know the size groups they belong to.

${ }^{4}$ Each firm has one or more industries, based on the industries of the plants belonging to the firm. There are enough changes in industries and/or plants to identify the industry effects also in fixed effects estimation.

5 The variables that describe the characteristics of the work force (average education, tenure, and age), labour productivity, and employment growth have been calculated from the original FLEED data, i.e. the "total" data and not our sample data.

${ }^{6}$ The estimation period starts from 1996, because data on some of the variables are lacking in the earlier years.
} 
Figure 7. Development of firm size effects over time.

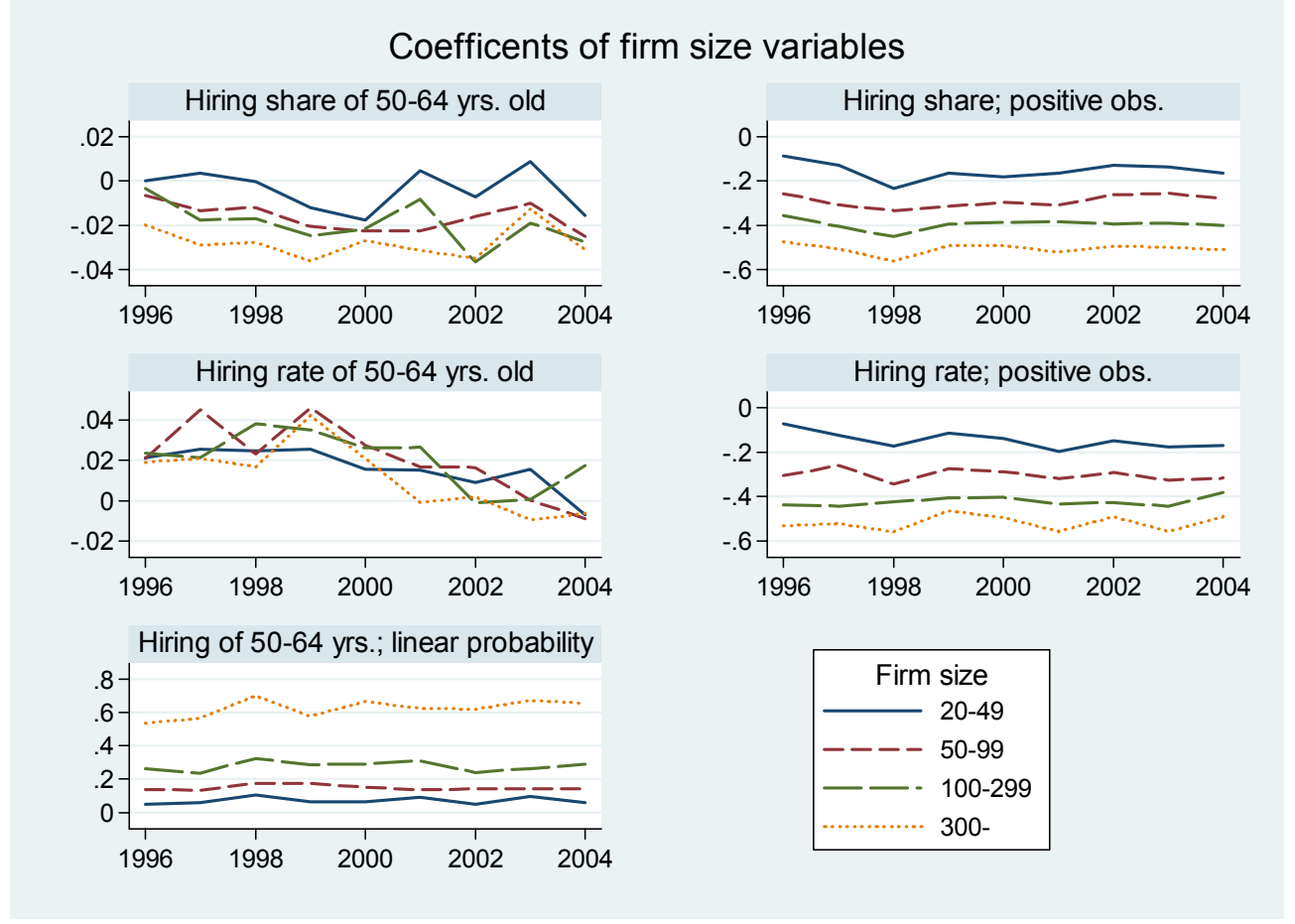

Table 1 shows the fixed effects estimation results for the whole period 1996-2004. The first two columns show the results for the hiring share of older employees, the next two for the hiring rate, and the last column for the linear probability model. ${ }^{7}$

The firm size coefficients are consistent with the annual cross section results. We have included past exit share or past exit rate of older employees to examine whether there is age-related replacement hiring. The coefficients of the exit variables are positive and significant in all but one of the models. This shows that there is indeed some replacement of exiting older employees by other old ones. One interpretation of this is that firms have such tasks that require long experience. Past growth is negatively related to the hiring share of the old, but not significant in the models for hiring rates. A notable difference to the other models is that according to the linear probability model firms that have grown in the past are more likely to hire old employees. It seems that when firms grow, they have to rely on more sources of new employees, including the older cohorts. The firms, whose hiring needs are smaller, can more easily pick up the kind of age structure they want.

\footnotetext{
${ }^{7}$ The number of observations varies in the estimations. The hiring share is not defined when a firm has no hiring and the hiring rate is not defined when a firm has not hired older employees and has not had them in the previous year, since the denominator of the rate is zero in this case. However, the hiring rate can still be zero when the hiring share does not exist (the plant has some older employees, but has not hired anyone), or vice versa (the plant has some hiring, but has no older employees).
} 
Past productivity has mixed influences, so there is no clear evidence of achievement of high productivity requiring a younger work force.

The results on the work force structure variables are somewhat mixed. Average age of employees is negatively related to hiring of the old, except in the model for positive hiring shares. It seems that firms want to achieve a balanced age structure. The hiring rates of the old are higher in firms with high educational level. Finally, average tenure in the firm is positively related to the hiring rate and the probability to hire old workers. The results can be interpreted to show that firms that need an educated and experienced work force tend to hire also older applicants.

The foreign ownership and foreign trade variables can be interpreted as measures of globalization. Since they are not significant in any of the estimations, it seems that there is no clear connection between globalization trends and the labour market prospects of the older employees. Finally, the unreported year effects show that there has been an increase in the hiring share of older employees and in the probability to hire any old employees during the data period. This is consistent with the policy efforts that have aimed at improving the labour market prospect of ageing workers. However, it also reflects cohort effects as the big post-war cohorts have entered the oldest age group, thereby increasing their share in the available labour supply. The hiring rate of the older employees has, on the other hand, declined during our estimation period. 
Table 1. Fixed effects estimation results for 1996-2004.

\begin{tabular}{|c|c|c|c|c|c|}
\hline & Hiring share & $\begin{array}{l}\text { Hiring share, } \\
\text { positive obs. }\end{array}$ & Hiring rate & $\begin{array}{l}\text { Hiring rate, } \\
\text { positive obs. }\end{array}$ & $\begin{array}{l}\text { Linear prob. for } \\
\text { positive obs. }\end{array}$ \\
\hline \multirow[t]{2}{*}{ 20-49 employees } & 0.009 & $-0.114 * * *$ & $0.035 * * *$ & $-0.091 * * *$ & $0.066^{* * *}$ \\
\hline & $(0.010)$ & $(0.033)$ & $(0.008)$ & $(0.035)$ & $(0.013)$ \\
\hline \multirow[t]{2}{*}{ 50-99 employees } & -0.007 & $-0.198 * * *$ & $0.041 * *$ & $-0.274 * * *$ & $0.144 * * *$ \\
\hline & $(0.013)$ & $(0.043)$ & $(0.017)$ & $(0.066)$ & $(0.020)$ \\
\hline \multirow[t]{2}{*}{ 100-299 employees } & -0.015 & $-0.266 * * *$ & $0.051 *$ & $-0.337 * * *$ & $0.256 * * *$ \\
\hline & $(0.015)$ & $(0.048)$ & $(0.026)$ & $(0.089)$ & $(0.030)$ \\
\hline \multirow[t]{2}{*}{ 300- employees } & -0.019 & $-0.312 * * *$ & $0.066^{* *}$ & $-0.371 * * *$ & $0.420 * * *$ \\
\hline & $(0.017)$ & $(0.051)$ & $(0.033)$ & $(0.111)$ & $(0.040)$ \\
\hline \multirow[t]{2}{*}{ Exit rate of 50- old, t-1 } & & & $0.211 * * *$ & $0.254 * * *$ & \\
\hline & & & $(0.012)$ & $(0.018)$ & \\
\hline \multirow[t]{2}{*}{ Exit share of 50- old, t-1 } & $0.022 * * *$ & 0.001 & & & $0.060 * * *$ \\
\hline & $(0.007)$ & $(0.013)$ & & & $(0.017)$ \\
\hline \multirow[t]{2}{*}{ Employment change, t-1 } & $-0.013^{*}$ & $-0.035^{* *}$ & -0.009 & -0.021 & $0.046 * * *$ \\
\hline & $(0.007)$ & $(0.015)$ & $(0.012)$ & $(0.024)$ & $(0.016)$ \\
\hline \multirow[t]{2}{*}{ Average age, $t-1$} & $-0.003 * *$ & $0.003^{* *}$ & $-0.010 * * *$ & $-0.021 * * *$ & $-0.010 * * *$ \\
\hline & $(0.001)$ & $(0.002)$ & $(0.003)$ & $(0.006)$ & $(0.003)$ \\
\hline \multirow[t]{2}{*}{ Average education, t-1 } & 0.005 & 0.017 & $0.068 * * *$ & $0.193 * * *$ & 0.002 \\
\hline & $(0.006)$ & $(0.011)$ & $(0.012)$ & $(0.034)$ & $(0.015)$ \\
\hline \multirow[t]{2}{*}{ Average tenure, $\mathrm{t}-1$} & 0.004 & -0.003 & $0.007^{*}$ & $0.011^{*}$ & $0.024 * * *$ \\
\hline & $(0.003)$ & $(0.004)$ & $(0.004)$ & $(0.006)$ & $(0.005)$ \\
\hline \multirow[t]{2}{*}{ Productivity, t-1 } & $-0.045^{* *}$ & -0.025 & 0.015 & $0.096^{*}$ & -0.030 \\
\hline & $(0.023)$ & $(0.025)$ & $(0.029)$ & $(0.054)$ & $(0.056)$ \\
\hline \multirow[t]{2}{*}{ Foreign } & -0.000 & -0.005 & 0.003 & 0.017 & 0.014 \\
\hline & $(0.006)$ & $(0.009)$ & $(0.011)$ & $(0.021)$ & $(0.035)$ \\
\hline \multirow[t]{2}{*}{ Exporter } & 0.008 & 0.015 & 0.012 & 0.015 & -0.007 \\
\hline & $(0.007)$ & $(0.012)$ & $(0.008)$ & $(0.013)$ & $(0.023)$ \\
\hline \multirow[t]{2}{*}{ Importer } & -0.002 & 0.007 & -0.002 & 0.012 & -0.007 \\
\hline & $(0.005)$ & $(0.007)$ & $(0.009)$ & $(0.017)$ & $(0.016)$ \\
\hline $\mathrm{N}$ & 45865 & 12170 & 65664 & 12903 & 61261 \\
\hline $\mathrm{R}^{2}$ within & 0.020 & 0.078 & 0.097 & 0.214 & 0.027 \\
\hline
\end{tabular}

Note: Robust standard errors in parentheses. ${ }^{*} \mathrm{p}<0.10,{ }^{*} \mathrm{p}<0.05,{ }^{*} \mathrm{p}<0.01$. Weighting by the number of employees is used in the estimations. Coefficients of year and industry dummies not reported. 


\section{CONCLUSIONS}

We have investigated the behaviour of firms in hiring of older employees during the time interval from 1992 to 2004 in Finland using linked employer-employee data. Our results using segregation curves and Gini indices indicate that hiring of older employees is much more segregated than exits, which in turn are more segregated than the stock of older employees. During a ten year time interval (from 1994 to 2004) the stock and exits of older employees have become more segregated, but hiring slightly less segregated. Approximately half of hiring of younger employees happened in workplaces that did not hire older employees. We compare the segregation both to the case of even allocation of employees (all firms hire or employ the same share of old employees) and to random allocation (the old and young employees in the data are randomly reshuffled to firms). Although comparison to random allocation shows less segregation, the main results and trends are similar to those in the comparison to even allocation.

There is a positive upward trend in the recruitments of the employees who are 50+. This trend is related to the increasing cohort size, but it is much weaker than the trend in the relative share of older workers in employment. The exit rate of the older employees indicates cyclical variation while the small number of hirings seems to be insensitive to changing labour demand. We also present a decomposition of employment by age group to hiring and exits and cohort related factors. For example the change in the number of employees in the age group 50-64 can be decomposed to hired and exited 50-64 olds, and to cohort differences among the staying employees (difference of those who were 49 and those who were 64 last year). The role of the cohort size effects is important in the oldest age groups and it is strengthened by the relatively high employment rates among the baby-boom generation.

We have found in a regression analysis that there are differences between different sized firms in their hiring behaviour. Larger firms tend to have lower share of old hires and lower hiring rates of the old, and there has been a trend over time which increases the gap to the smallest firms. However, larger firms have a higher probability to higher any old employees, although when they hire, their hiring rate is lower.

The results also have implications for policies aiming to lengthen the working careers and increase the sustainability of pension systems. These targets have made it necessary to restrict the use of early retirement. However, it is not enough. Older worker who have become unemployed or who want to change their job need to have more employment opportunities than is the case at the 
moment. Labour and pension policies need to be monitored and designed so that there are more incentives for the individual to search for a new job and for the firms to hire older employees.

\section{REFERENCES}

Adams, S.J., "Age discrimination legislation and the employment of older workers", Labour Economics 11, 2004, 219-241.

Adams, S.J. and Heywood, J.S., "The age of hiring and deferred compensation: evidence from Australia", Economic Record 83, 2007, 174-190.

Aubert, P., Caroli, E., and Roger, M., "New technologies, organization and age: firm-level evidence", Economic Journal 116, 2006, F73-F93.

Behaghel, L., Crépon, B., and Sédillot, B., "The perverse effects of partial employment protection reform: The case of French older workers", Journal of Public Economics 92, 2008, 696-721.

Bellman, L. and Brussig, M., "Recruitment and job applications of older jobseekers from the establishments' perspective", IZA Discussion Paper No. 2721, 2007.

Carrington, W.J. and Troske, K.R., "On measuring segregation in samples with small units", Journal of Business and Economic Statistics 15, 1997, 402-409.

Daniel, K. and Heywood, J.S., "The determinants of hiring older workers: UK evidence", Labour Economics $14,2007,35-51$.

Daniel, K. and Siebert, W.S., "Does employment protection reduce the demand for unskilled labour?", International Economic Journal 19, 2005, 197-222.

Disney, R., Hawkes, D. and Heden, Y., "Declining job opportunities for older workers in Britain: the role of job-specific characteristics", University of Nottingham, mimeo, 2006.

Duncan, O.D. and Duncan, B., "A Methodological Analysis of Segregation Indexes”, American Sociological Review 20, 1955, 210-217.

Garen, J., Berger, M., and Scott, F., "Pensions, non-discrimination policies, and the employment of older workers", Quarterly Review of Economics and Finance 36, 1996, 417-429.

Hairault, J.-O., Langot, F., and Sopraseuth, T., "Distance to retirement and older workers' employment: The case for delaying the retirement age", Journal of the European Economic Association 8, 2010, 1034-1076.

Hakola, T. and Uusitalo, R., "Not so voluntary retirement decisions", Journal of Public Economics 89, 2005, 2121-2136.

Heywood, J.S., Ho, L.-S., and Wei, X., "The determinants of hiring older workers: evidence from Hong Kong", Industrial and Labor Relations Review 52, 1999, 444-459.

Heywood, J.S., Jirjahn, U., and Tsertsvardze, G., "Hiring older workers and employing older workers: German evidence", Journal of Population Economics 23, 2010: 595-615.

Heywood, J.S. and Siebert, W.S., "Understanding the Labour Market for Older Workers: A Survey", IZA Discussion Paper No. 4033, 2009. 
Hirsch, B., Macpherson, D.A., and Hardy, M.A., "Occupational age structure and access for older workers", Industrial and Labor Relations Review 53, 2000, 401-418.

$\mathrm{Hu}, \mathrm{L}$. , "The hiring decisions and compensation structures of large firms", Industrial and Labor Relations Review 56, 2003, 663-681.

Hutchens, R., "Delayed payment contracts and a firm's propensity to hire older workers", Journal of Labor Economics 4, 1986, 439-457.

Hutchens, R, “Do job opportunities decline with age?”, Industrial and Labor Relations Review 42, 1988, 8999.

Ilmakunnas, P. and Ilmakunnas, S., "Hiring older employees: Do incentives of early retirement channels matter?” Labour Institute for Economic Research, Discussion Paper No. 268, 2011.

Ilmakunnas, P. and Maliranta, M. "Worker inflow, outflow, and churning", Applied Economics 37, 2005, 11151133.

Ilmakunnas, S. and Takala, M., "Promoting employment among ageing workers: lessons from successful policy changes in Finland", Geneva Papers on Risk and Insurance - Issues and Practice 30, 2005, 674-692.

Kyyrä, T. and Ollikainen, V., "To search or not to search? The effects of UI benefit extension for the older unemployed", Journal of Public Economics 92, 2008, 2048-2070.

Kyyrä, T. and Wilke, R., "Reduction in the long-term unemployment of the elderly: a success story from Finland", Journal of the European Economic Association 5, 2007, 154-182.

Lazear, E., "Why is there mandatory retirement", Journal of Political Economy 87, 1979, 1261-1284.

Munnell, A. and Sass, S.A., Working Longer. The Solution to the Retirement Income Challenge, Washington D.C.: Brookings Institution Press, 2008.

Pfeifer, C., "An intra-firm perspective on wage profiles and employment of older workers with special reference to human capital and deferred compensation", Leibniz Universität Hannover, Institute of Labour Economics, Discussion Paper No. 413, 2009.

Saint-Paul, G., "Does the welfare state make older workers unemployable?", IZA Discussion Paper No. 4440, 2009.

Scott, F.A., Berger, M.C., and Garen, J.E., "Do health insurance and pension costs reduce the job opportunities of older workers?", Industrial and Labor Relations Review 48, 1995, 775-791

Zwick, T., "Consequences of Seniority Wages on the Employment Structure", Industrial and Labor Relations Review, forthcoming. 